\title{
Escapist Technology in the Service of Neo-Feudalism
}

\author{
Dimitry Kochenov
}

This contribution agrees with Rainer Bauböck's reaction to Liav Orgad's opening statement. I am, too, 'less optimistic about the future of citizenship'. My reasons are different though. There are different ways to go about technological leaps: to turn technological breakthroughs into the tools of improving the long-established reality, or to revolutionize society based on technological advancements. Nikolai Fëdorov, to give an ambitious example, aimed at conquering death and resurrecting all those previously living. ${ }^{1}$ Liav Orgad's text proposes technology-inspired change. I suggest, respectfully, that by not going far enough, what is proposed by Orgad could turn out to be dangerous and unwelcome for a large share of the world population outside of the richest countries. Echoing Lea Ypi's contribution, I suggest that it will do more harm than good. The reason for this is that it puts technology to the service of the mythology of citizenship, instead of interrogating citizenship's essence and functions and questioning its darker corners.

The core of the problem, to my mind, is the concept of citizenship as such, not the documentation of identity, which the blockchain proposal addresses. Virtual nations, as long as they replicate existing national structures that randomly ascribe strict identities and reinforce deep global inequalities, will make the world worse off, especially among its poorest half. Even if they miraculously end up playing a significant role, the citizenship framing of the issues Orgad aims to address seems to be unhelpful and problematic, especially in the context of his rhetoric aspiring to reach out to 'global' citizenship, whatever this could mean.

Citizenship is a racist and sexist status of randomised violent segregation of the world population into relatively closed groups of varying objective value from the point of view of individual rights. ${ }^{2}$ Some come with farreaching rights - others with liabilities. Both are significant both in real life

\footnotetext{
Fëdorov, N. F. (1906), Filosofija obshchego dela. Moscow: Vernyj.

2 Kochenov, D. (2019), Citizenship: An Alchemist's Promise. Michigan: MIT

Press (forthcoming).
} 
and in the cloud. If someone is assigned a humiliating set of liabilities in real life, say, a Central African Republic citizenship, instead of a noble and democratic status boosting one's rights, say the citizenship of France, cloud communities will not change that, unless the distinction between being assigned to CAR as opposed to France is thereby undermined, and based on Orgad's suggestion it won't be. The 'real life' problem thus derives from real life inequalities between citizenships as bundles of rights and liabilities. It is not only that citizenships by definition exclude. It is the difference between different citizenships that matters. As long as these two premises persist in shaping our day-to-day reality, a 'global' cloud community is a meaningless proposition for those who hold inferior citizenships, reinforcing the gaps between CAR citizens and the French.

Citizenship's core function throughout history, alongside sexism and a deep exclusion of women, has been to establish and police global race- and wealth-based hierarchies of opportunities and rights, while providing an impenetrable and punishing noble façade of equality and self-determination. In this, citizenship has been very effective: it took US women almost hundred years to get the right to vote and the Dutch ones waited until 1986 to have a citizenship status independent of that of their husbands. Compared with women, all the colonial subjects fared significantly worse. While African Americans obviously have not been enjoying the same rights as 'Caucasian' US citizens throughout the history of US citizenship, the same is true for the European and Asian empires as well. Emmanuelle Saada explains how arbitrary and uniquely based on skin-colour the ascription of Frenchness in the colonies of the Republic was. ${ }^{3}$ What decolonisation brought, however, was a racial segregation of the world under the banner of equal citizenship among equal states. All the former colonial subjects are now confined to the places around the world reserved uniquely for the losers of Ayelet Shachar's infamous birthright lottery. ${ }^{4}$ The only difference compared with seventy years ago is that there is no more French judge in the former colony, whom you can beg for a drastic status upgrade for your child, capitalising on her unexpected blue eyes - racism is outlawed, remember?

The world has thus both changed and remained the same. It changed, because since the Second World War the Western world has come to accept women as the bearers of citizenship status independent of their sexual

\footnotetext{
Saada, E. (2012), Empire's Children: Race, Filiation, and Citizenship in the French Colonies. Chicago: Chicago University Press.

4 Shachar, A. (2009), The Birthright Lottery: Citizenship and Global Inequality. Harvard: Harvard University Press.
} 
partners and even grants them political rights. Racial minorities within 'first world' states are also respected - both on paper and often in practice too. The façade of citizenship as a status of equals seems to have met - for the first time since its proclamation by Aristotle - its promise. Yet the world has also remained hugely unequal. Branko Milanovic teaches us that, although global income inequalities have recently declined when measured by country averages, country of residence is more important than class today. Even the 'occupy Wall Street' guys belong in fact to the world's elites, they are only not able to realise the depth of misery of others. Indeed, those locked into the poorest former colonies do not inhabit the same narrative as Europeans and Americans. The main purpose of citizenship has been upgraded: from a neo-feudal mechanism of sexist and racist governance, it is turning into one of the core instruments of preservation and justification of global inequality, hiding its functionality behind the old façade of political self-determination, which had been effective to brush away women and minorities before.

Citizenships are thus about preserving inequality worldwide. As long as segregating remains citizenships' main function, cloud communities are powerless in their mission: identities are irrelevant as long as all the life chances or the lack thereof depend on a random legal status of ascription to authority distributed at birth. Worse still, humiliation and randomness are routinely sanctified: while upholding and perpetuating inequality, citizenship supplies a powerful and ultimately pointless narrative justifying random privilege through the glorification of expediency in territorial governance.

The lack of any rights worldwide coming with some citizenships as opposed to a huge bundle of rights coming with others can be measured. By comparing GDP, HDI, travel freedom and settlement and work rights abroad it is easy to see why being born French - with a status welcoming you to the job market of 41 countries and all the other perks included - is infinitely better than being a Ukrainian or, God forbid, an Afghani. The Quality of Nationality Index, which I designed together with Chris Kälin shows this in the most graphic way (http://www.nationalityindex.com). For ordinary people this is not all theory: the boats crossing the Mediterranean are full and they cross the sea in one direction only. My point is, they will be going the same way no matter what cloud communities are introduced, since the

Milanovic, B. (2012), 'Global Income Inequality by the Numbers: In History and Now', Policy Research Working Paper No. 6259, The World Bank, available at http://documents.worldbank.org/curated/en/959251468176687085/ Global-income-inequality-by-the-numbers-in-history-and-now-an-overview 
violence of global segregation that citizenship inflicts cannot be affected by the technology proclaiming an abstract 'global citizenship' to be a value and reaffirming it in the cloud.

Before discussing the potential benefits of a set of quasi-citizenships in the cloud it is crucial to be fully aware of the drastic differences between citizenships in 'real life' and fully internalise their ability to punish besides simply segregating at random. Pace Arendt's 'right to have tights' citizenship is a status associated with rights in a handful of countries only. In many others, it is a severe and undeserved liability and sometimes a mortal one. What blockchain offers to a Frenchmen will thus be radically different from what it offers to a Congolese (pick your Congo!). When refugees arrive in Europe or America, they often destroy, sometimes even eat, their passports. Have you tried to consider why? It is because many citizenships are so terribly poisonous and dangerous that you might be infinitely better off as a stateless person. This is because with a Central African Republic passport your child born in Brussels will be a Central African, not a Belgian, because you will need to wait for naturalisation longer and, ultimately, because CAR will have to accept you back once you are out of the Belgian asylum system. To be identifiable is always as bad a liability as the citizenship or the place of birth you will be identified with. It can ruin lives. This is where cloud communities come in as an impermissibly rosy dream. The proposal ignores the complexity of the world and fails to fully come to terms with its own dangers in the context of the current functions of citizenship behind the selfjustificatory sacred façade put up uniquely for those who somehow happen to belong to the right country in order to let them sleep tight at night.

Citizenship's inescapable evil does not stem from the fact that it is a randomly assigned benefit, but from the reality that it is about branding as deficient those who are randomly proclaimed not to belong while treating such exclusion as self-explanatory and just. This justice is ethically void, however, as long as we believe that it is humanity that counts morally and that obliges us to respect others' desire to live a worthy life, as Joseph Carens has demonstrated. ${ }^{6}$ Should this indeed be our starting point, any serious work to perfect the current citizenship paradigm - either on the ground or in the cloud - is nothing else but work that opposes ethical imperatives we all share. The untenability of citizenship's ethical narrative, no matter which way of telling it one chooses, is the elephant in the room, which ultimately explains the on-going demise of the citizenship of the 'good old times': a random supremacist status for armed white boys who belong and believe in

6 Carens, J. (2013), The Ethics of Immigration. Oxford: Oxford University Press. 
the greatness of their land, whatever it might be, often at the expense of all their neighbours.

How do the cloud communities proposed by Orgad fit Joppke's story of the 'inevitable lightening of citizenship'? ${ }^{7}$ In the former imperial centres such luxury as new online associations emerging through the individual sovereign governance of identity with the help of blockchain as Orgad describes it is only welcome - our world is open and ripe with opportunities - in the cloud and on the ground. About the rest of the world I am somewhat sceptical: as Robert Post has already suggested in his contribution, life in the place where you are is something that is of crucial importance, more than your cloud identity, whatever that would come to mean. And as Michael Blake points out, violence in the physical world is equally crucial. Work and education of your choosing, residence abroad, freedom of belief and expression, an ability to be with your loved ones, to go places - this is what a Saudi citizenship, now grotesquely granted to a robot, will no doubt deny you, especially if you are a woman. Using technology for escapism is something that falls far short, it seems to me, of its potential. A cloud community will not even save you from beheading in Saudi Arabia for confessing atheism online, for instance, or, if you happen to be a Chinese national, spending three years in jail for calling $\mathrm{Mr} \mathrm{Xi}$ a 'steam bun' in a private chat conversation in your cloud.

Once escapism has been discarded, it becomes necessary to consider what cloud communities could be good for. And in doing so it is our imperative not to replicate the repugnant nature of citizenship as a justificatory label for random privilege and for explaining away global inequality. Here Estonia shows the way, as Poleshchuk has demonstrated. ${ }^{8}$

It is not the cloud identity, - I am gay in the cloud since otherwise the government will kill me - it is the functional added value of the virtual statuses and 'residences' that should come to the fore. What I am saying is that clubs, no matter whether offline or in the cloud, have nothing to do with citizenships, since citizenships are involuntary and do not foster common interests or values. Consequently, calling any cloud identities 'citizenship' is a misconception. One needs to move on from citizenship when technology allows. What is possible today - and this is a great beginning Estonia

Joppke, C. (2010), Citizenship and Immigration. London: Polity.

P Poleshchuk, V. (2016). "“Making Estonia Bigger": What E-Residency in

E-Estonia Can Do for You, What It Can Do for Estonia', Investment Migration

Working Papers. Available at https://investmentmigration.org/download/ making-estonia-bigger-e-residency-e-estonia-can-can-estonia/ 
started - is to use online residences as compensation mechanisms for the deficiencies of the statuses of citizenship, which the vast majority of the world's population got by birth. You are born in Afghanistan? Fine, with an Estonian residency online you can at least open a proper bank account and have access to basic state services - notaries, company registers etc. This is a primary use of new digital technologies.

A second purpose - and this one should be based on a broad agreement between states - is to use attested individual identities to judge people by those, rather than their passports. Crucially, these cannot go hand in hand. The core added value would be to replace one with the other. We are a long way from here and the connection between the cloud and 'real life' is crucial here, but what one can envisage is a world where babies in Afghanistan or Pakistan are born without at least some of the drastic harmful effects of the original sin of nationality and that peoples' worth at international borders is assessed via some factors other than the particular state that has been claiming the possession of them from birth. This should be the future of technological thinking to bring true liberation from the neo-feudal essence of a poisonous status, which is ethically vacuous, its political expediency notwithstanding. A technological revolution should not become a servant of the status quo, erecting yet higher walls between the haves and have-nots.

Open Access This chapter is licensed under the terms of the Creative Commons Attribution 4.0 International License (http://creativecommons.org/licenses/by/4.0/), which permits use, sharing, adaptation, distribution and reproduction in any medium or format, as long as you give appropriate credit to the original author(s) and the source, provide a link to the Creative Commons license and indicate if changes were made.

The images or other third party material in this chapter are included in the chapter's Creative Commons license, unless indicated otherwise in a credit line to the material. If material is not included in the chapter's Creative Commons license and your intended use is not permitted by statutory regulation or exceeds the permitted use, you will need to obtain permission directly from the copyright holder.

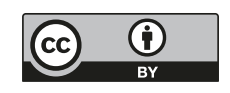

